
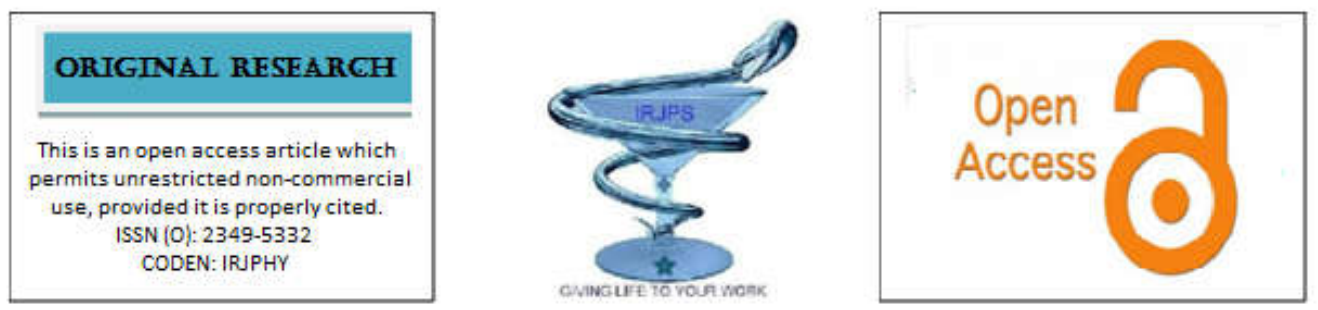

\title{
RISK OF CONSTIPATION WITH CALCIUM CARBONATE/MAGNESIUM CARBONATE COMBINATION CHEWABLE TABLETS VERSUS CALCIUM CARBONATE TABLETS IN HEMODIALYSIS PATIENTS.
}

\author{
Amer Nabieh Afram Al-hourani, “Moh'd Nour” Mahmoud Bani Younes, Ala' Mohammad \\ Alfaraheed, Jalela Sharari Ali Al Kaabneh, Marwah Bassam Al-Omoush, Jaafar Abd Alrahman
}

Abu Abeeleh

Royal Medical Services, Jordan

\section{Submitted on: 19.11.18; $\quad$ Revised on: 27.11.18; $\quad$ Accepted on: 29.11.18}

\section{ABSTRACT:}

Objectives: The aim of this study is to evaluate the differences between the two calcium supplements on hemodialysis patients in terms of corrected calcium level, serum $\mathrm{Mg}^{+2}$ level, and Constipation Scoring System (0-30) value.

Methods: The randomized, controlled, open study was conducted at renal /hemodialysis unit of King Hussein Medical Center for six weeks. Patients who met the inclusion criteria were enrolled and randomly allocated into either interventional groups (Group I or II) or control groups (Group III or IV). Group I\& III included hemodialysis patients who took proton pump inhibitors, while Group II \& IV included hemodialysis patients who took $\mathrm{H}_{2}$ B Blockers.

Results: The mean age was $40.81 \pm 2.31$ years, and 37 participants $(52.11 \%)$ were males. Constipation Scoring System (0-30) value was decreased significantly in Group I (-12 (8)) and Group II (-9 (20)) after $\mathrm{CaCO}_{3}$ tablets were totally replaced by $\mathrm{CaCO}_{3} / \mathrm{MgCO}_{3}$ combination chewable tablets. This significant decrease in Constipation Scoring System (0-30) was accompanied by insignificant increase in the levels of serum corrected calcium $(+0.21 \pm 0.47$ vs $+0.08 \pm 0.48$, respectively) at the cost of statistically but not clinically significant increase in the levels of magnesium ( $+0.3 \pm 0.34 \mathrm{vs}+0.55 \pm 0.36$, respectively).

Conclusion: $\mathrm{CaCO}_{3} / \mathrm{MgCO}_{3}$ com=bination chewable tablets may safely be used as first line phosphate binder/calcium supplement instead of the traditional first line phosphate binder/calcium supplement $\mathrm{CaCO}_{3}$ tablets in hemodialysis patients who are taking either PPIs or $\mathrm{H}_{2}$-Blockers with a positive impact on severity and frequency of constipation and statistically but not clinically significant risk of persistent hypermagnesemia, especially when we used PPIs rather than $\mathrm{H}_{2}$-Blockers.

Key words: Hemodialysis, Calcium supplement, Constipation, Magnesium.

Corresponding author: Jaafar Abd Alrahman Abu Abeel

E-mail: ayhamjafar@yahoo.com

Indian Research Journal of Pharmacy and Science; 19(2018)1658-1668; Journal Home Page: https://www.irjps.in DOI: 10.21276/irjps.2018.5.4.4 


\section{INTRODUCTION:}

Hyperphosphataemia is an independent predictor of mortality in advanced chronic kidney disease (CKD) patients and it is typically managed with oral phosphate binders, especially calcium-based binders which have historically been an appealing first choice, because they are inexpensive and theyalso address the hypocalcemia that is often seen in hemodialysis (HD) patients ${ }^{1-4}$. Calcium based phosphate binders may also account for up to $50 \%$ of the daily pill burden in HDpatients together with frequent gastrointestinal adverse drug effects (particularly constipation) which may contributes to poor medication ${ }^{5,}{ }^{6}$.Higher acid production can occur secondary to hypergastrinemia as a consequence of decreased clearance of gastrin and increased density of $G$ cells that secrete gastrin secondary to a hyperparathyroidism in CKD patients ${ }^{7-9}$. So, due to its $\mathrm{pH}$-dissolution rate dependent, calcium carbonate $\left(\mathrm{CaCO}_{3}\right)$ has a long disintegration time when it is co-administered with $\mathrm{H}_{2}$ Blockers or proton pump inhibitors (PPIs) that explains the frequently needed high daily pill burden of $\mathrm{CaCO}_{3}$ to be effective as phosphate binder and calcium supplement, which can result in increase the frequency and prevalence of constipation episodes, altered dietary intake, and subsequently decrease overall quality of life in HD patients ${ }^{10-14}$.

The $\mathrm{CaCO}_{3} / \mathrm{MgCO}_{3}$ combination chewable tablet $\left(\right.$ Rennie $^{\circledR}$ ) is a chewable tablet contains 80 mg magnesium carbonate $\left(\mathrm{MgCO}_{3}\right)$ and $680 \mathrm{mg}$ $\mathrm{CaCO}_{3}$, so that chewing or sucking two tablets of $\mathrm{CaCO}_{3} / \mathrm{MgCO}_{3}$ combination chewable tablet after a meal will be almost equal in mg basis of calcium content to swallowing one tablet of $\mathrm{CaCO}_{3} 1250 \mathrm{mg}$ with a meal. In addition, the 80 $\mathrm{mg}$ of $\mathrm{MgCO}_{3}$ in $\mathrm{CaCO}_{3} / \mathrm{MgCO}_{3}$ combination chewable tablet may minimize the constipation effect of $\mathrm{CaCO}_{3}$ due to $\mathrm{Mg}^{+2}$ opposite laxative effect on gastrointestinal motility in contrast to $\mathrm{Ca}+{ }^{2}$ constipating effect, may minimize the risk of hypercalcemia and subsequently risk of vascular calcification due to magnesium competition with calcium $^{15-17}$. A lower cost and $\mathrm{pH}$ dissolution dependentphosphate binder/calcium supplement combining a reduced calcium exposure and the possible beneficial effect of controlled magnesium administration, potentially seemed worthwhile to evaluate the differences between it and the traditional $\mathrm{CaCO} 3$ tablets on hemodialysispatients.

\section{METHOD:}

This randomized, controlled, open label study was conducted at renal /hemodialysis unit of King Hussein Medical Hospital (KHMH) for six weeksin order to evaluate the differences between four groups as defined in Table (1) in terms of corrected calcium level, serum $\mathrm{Mg}^{+2}$ level, and Constipation Scoring System (0-30) value.

Table 1: HD participant groups candidate for study

\begin{tabular}{|c|c|c|c|}
\hline Group I & Group II & Group III & Group IV \\
\hline $\begin{array}{c}\text { HD participants who are } \\
\text { taking PPIs }+ \\
\mathrm{CaCO}_{3} / \mathrm{MgCO}_{3} \\
\text { combination chewable } \\
\text { tablets. }\end{array}$ & $\begin{array}{c}\text { HD participants who are } \\
\text { taking } \mathrm{H}_{2} \text {-Blockers }+ \\
\mathrm{CaCO}_{3} / \mathrm{MgCO}_{3} \\
\text { combination chewable } \\
\text { tablets. }\end{array}$ & $\begin{array}{l}\text { HD participants who } \\
\text { are taking PPIs + only } \\
\mathrm{CaCO}_{3} \text { tablets. }\end{array}$ & $\begin{array}{c}\text { HD participants who are } \\
\text { taking } \\
\mathrm{H}_{2}-\mathrm{Blockers}^{+}+\text {only } \\
\mathrm{CaCO}_{3} \text { tablets. }\end{array}$ \\
\hline
\end{tabular}

CaCO3: Calcium carbonate; PPIs: Proton pump inhibitors; HD: Hemodialysis.

Group I: Hemodialysis participants who are taking PPIs $+\mathrm{CaCO}_{3} / \mathrm{MgCO}_{3}$ combination chewable tablets.

\section{Group II: Hemodialysis participants who are taking $\mathrm{H}_{2}$-Blockers $+\mathrm{CaCO}_{3} / \mathrm{MgCO}_{3}$ combination chewable tablets.}

Group III: Hemodialysis participants who are taking PPIs + only $\mathrm{CaCO}_{3}$ tablets.

Group IV: Hemodialysis participants who are taking $\mathrm{H}_{2}$-Blockers + only $\mathrm{CaCO}_{3}$ tablet.

After the study was approved from the IRB committees at the Jordanian Royal Medical
Services, patients in the renal /hemodialysis unit of KHMC who did met the inclusion and didn't 
met the exclusion criteria as described in Figure (1) wereenrolled in this study after they accepted to participate in this study, they were randomly allocated into either interventional groups (Group I and II) or control groups (Group III and IV).

The inclusion criteria for HD participants in this study included: Age greater than 18 years, age lower than 60 years, on chronic hemodialysis for at least three months, the $\mathrm{HD}$ participants used $\mathrm{CaCO}_{3}$ tablets as a phosphate binder and used either PPIs or $\mathrm{H}_{2}-$ Blockers for at least 3 months before participating in this study.

The exclusion criteria for HD patients in this study included: Serum $\mathrm{cCa}^{+2}$ level above $10.2 \mathrm{mg} / \mathrm{dl}, \mathrm{cCa}^{+2} \times \mathrm{PO}_{4}^{-3}$ above $55 \mathrm{mg}^{2} / \mathrm{dl}^{2}$, serum $\mathrm{Mg}^{+2}$ baseline level above $3.5 \mathrm{mg} / \mathrm{dl}$, there was a positive history of psychiatric or other disorders leading to compliance issues, and there was a positive history of dysphagia or swallowing disorders or bowel obstruction.

Figure 1: Inclusion and exclusion criteria for hemodialysis patients.

All possible retrospective data for Group I, Group II, Group III, and Group IV were collected before the study period was started. The retrospective data of three months ago included the last three values of serum corrected calcium levels, serum magnesium levels, and Constipation Scoring System (0-30) values.After retrospective data were completed, the four studied groups were followed for 6 weeks in which the following outcomes were measured and assessed in the following basis:

- Serum albumin and calcium levels (to calculate the corrected level of calcium) were measured on weekly basis for the first 2 weeks and then every other week for the remaining 4 weeks.

- Serum magnesium levels were measured on weekly basis for the first 2 weeks and then every other week for the remaining 4 weeks.

- Constipation Scoring System (0-30) valueswere assessed twice per week for six weeks.

In the interventional prospective follow-up, the $\mathrm{CaCO}_{3}$ tablets in both Group I and Group II were totally replaced by $\mathrm{CaCO}_{3} / \mathrm{MgCO}_{3}$ combination chewable tablets without a washout period (maximum 6 tablets per day)in which each 1 tablet of $\mathrm{CaCO}_{3} 1250$ mg was replaced by 2 tablets of $\mathrm{CaCO}_{3} / \mathrm{MgCO}_{3}$ combination $680 \mathrm{mg} / 80 \mathrm{mg}\left(\right.$ Rennie $^{\circledR}$ ), while keeping all other medications without any change. During the follow-up phase, if serum
$\mathrm{Mg}^{+2}$ level was $\geq 3.5 \mathrm{mg} / \mathrm{dl}$ and persisted for 1 week or serum $\mathrm{Mg}^{+2}$ level was $\geq 4.5 \mathrm{mg} / \mathrm{dl}$ we dropped-out the HD participant from our study. The $\mathrm{CaCO}_{3}$ tablets in the Group III and Group IV were kept without any change in the prospective follow-up phase.

The collected data at the end of 6 weeks of each desired outcome in the different four studied groups were analyzed using either Kruskal-Wallis Test followed by MannWhitney U-Test with Bonferroni correction for Constipation Scoring System (0-30) values or one-way ANOVA test followed by Tukey Kramer Post Hoc test for serum corrected calcium and serum magnesium levels (with $p$ value $<0.05$ as a level of significance) to determine whether there were significant differences. For each studied group of the four studied groups, mean $\pm \mathrm{SD}$ was compared between before interval versus after interval for serumcorrected albumin and serum magnesium levelsby using paired T-Test while median (Range) between before interval versus after interval was compared for Constipation Scoring System (0-30) values by using Wilcoxon Signed Ranks Test.One-Way ANOVA test analysis was used to present the demographic characteristics of age (years), body surface area (BSA) $\left(\mathrm{m}^{2}\right)$, body mass index (BMI) $\left(\mathrm{kg} / \mathrm{m}^{2}\right)$, duration of dialysis (months), duration of using $\mathrm{CaCO}_{3}$ tablets as phosphate binder/calcium supplement (months), duration of using either PPIs or $\mathrm{H}_{2}$ Blockers (months) and HD duration per session 
(hours) by comparing the mean \pm SEM among groups. In case of gender (male or female) and HD frequency per week (\%) data were presented as percentage of frequency.

\section{RESULTS:}

The recruitment, randomization, and dropout processes of all 142 eligible HD participants and the medical and medication history of the study candidates in each group of the four studied groups are summarized in Figure (2-4). All demographic characteristics of 71 HD participants in the four studied groups are summarized in Tables(2-3). All comparative results of the tested variables within and between four studied groups are summarized in Table (4-5).
A total of 71 hemodialysis patients were finally included in this study. The mean age was $40.81 \pm 2.31$ years, and 37 males (52.11\%) were male. Constipation Scoring System (0-30) value was decreased significantly in Group I (-12 (8)) and Group II (-9 (20)) after $\mathrm{CaCO}_{3}$ tablets were totally replaced by $\mathrm{CaCO}_{3} / \mathrm{MgCO}_{3}$ combination chewable tablets. This significant decrease in Constipation Scoring System (0-30) values was accompanied by insignificant increase in the levels of serum corrected calcium $(+0.21 \pm 0.47$ vs $+0.08 \pm 0.48$, respectively) at the cost of statistically but not clinically significant increase in the levels of magnesium $\quad(+0.3 \pm 0.34$ vs $+0.55 \pm 0.36$, respectively).

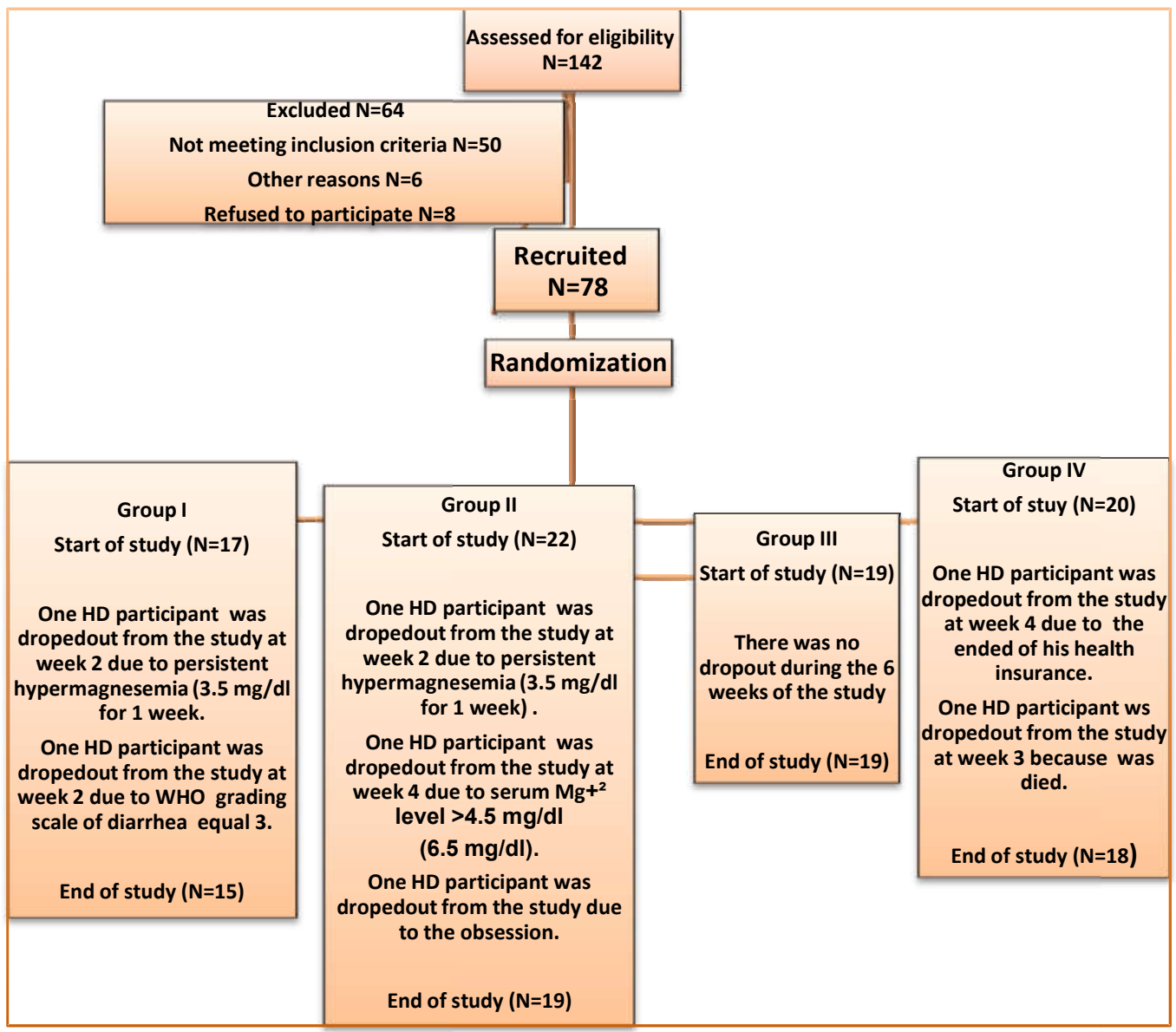

Figure 2: Recruitment, randomization, and dropout processes scheme 


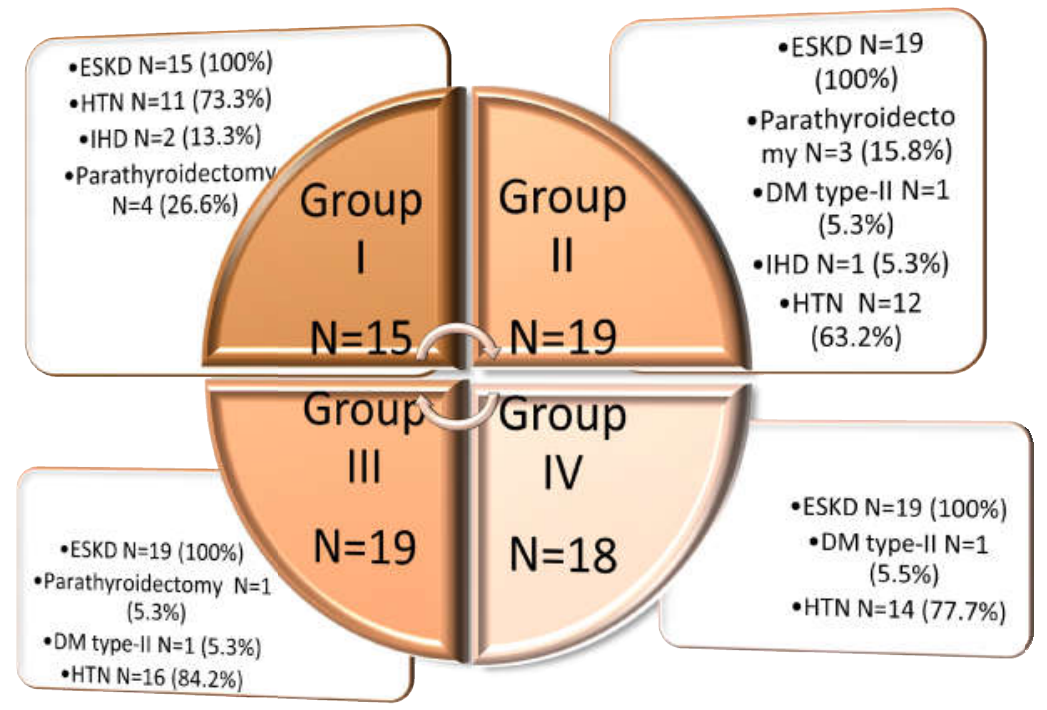

Figure 3: Patient's medical history of the HD participant patients presented as (percentage).

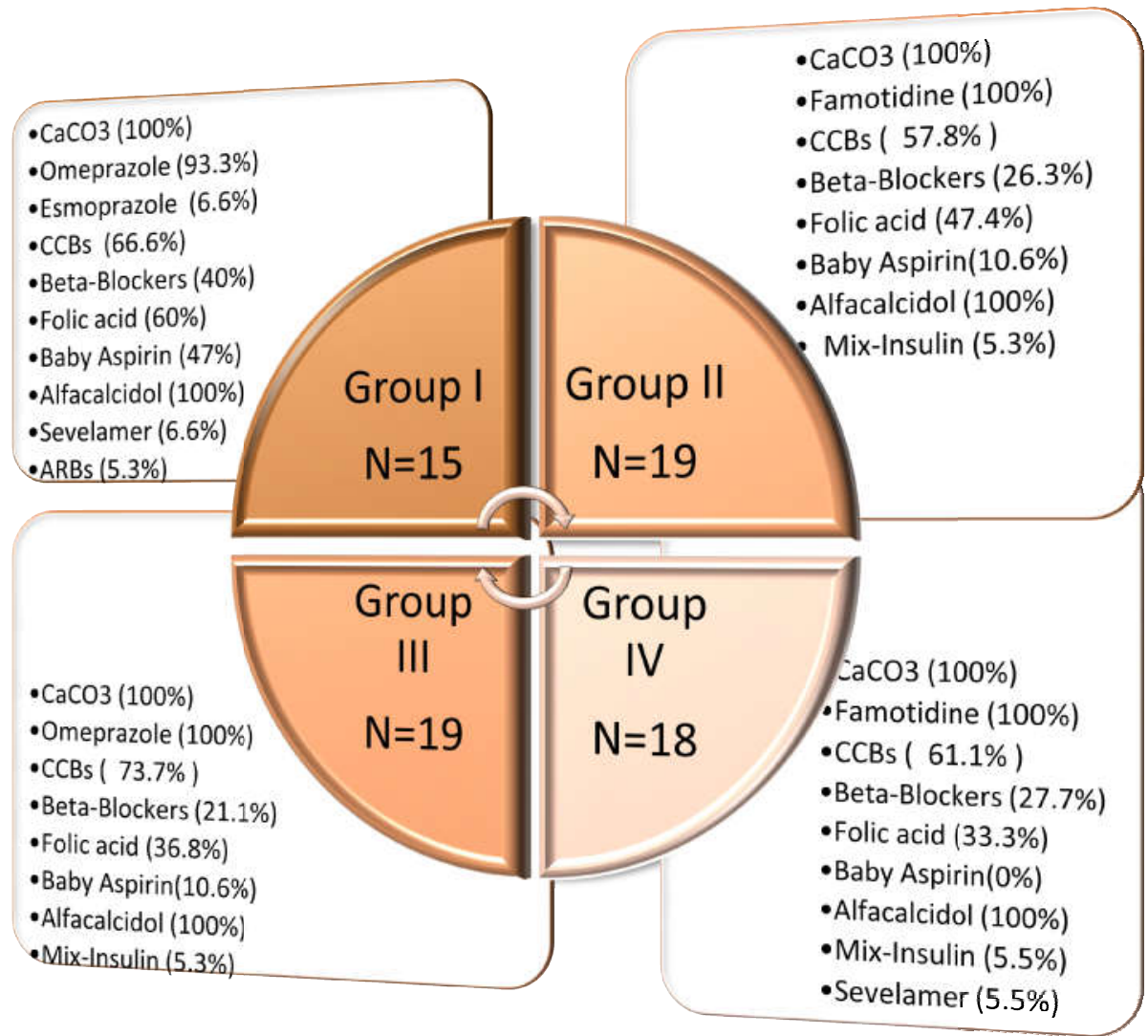

Figure 4: Current patient's medications history of the HD participant patients presented as (percentage). 
Table 2: Demographic characteristics of the four studied groups

\begin{tabular}{|c|c|c|c|c|c|c|c|c|c|}
\hline \multicolumn{3}{|c|}{ Characteristics } & Group I & Group II & Group III & Group IV & Total & $P-$ & Sig \\
\hline & & & Mean \pm SEM & Mean \pm SEM & $\operatorname{Mean} \pm \operatorname{SEM}$ & Mean \pm SEM & $\operatorname{Mean} \pm \operatorname{SEM}$ & & \\
\hline \multicolumn{2}{|c|}{ Age (years) } & КНМС & $41.86 \pm 2.41$ & $39.47 \pm 2.47$ & $38.68 \pm 2.32$ & $43.21 \pm 2.01$ & $40.81 \pm 2.31$ & 0.35 & NS \\
\hline \multirow[t]{2}{*}{ Sex } & $\begin{array}{c}\text { Male } \\
(\%)\end{array}$ & КНМС & $\begin{array}{l}8 \text { males } \\
(53.33 \%)\end{array}$ & $\begin{array}{l}7 \text { males } \\
(36.84 \%)\end{array}$ & $\begin{array}{l}12 \text { males } \\
(63.16 \%)\end{array}$ & $\begin{array}{l}10 \text { males } \\
(55.55 \%)\end{array}$ & $\begin{array}{l}37 \text { males } \\
(52.11 \%)\end{array}$ & \multirow[t]{2}{*}{0.44} & NS \\
\hline & $\begin{array}{c}\text { Female } \\
(\%)\end{array}$ & КНМС & $\begin{array}{l}7 \text { females } \\
(46.66 \%)\end{array}$ & $\begin{array}{l}12 \text { females } \\
(63.16 \%)\end{array}$ & $\begin{array}{l}7 \text { females } \\
(36.84 \%)\end{array}$ & $\begin{array}{l}8 \text { females } \\
(44.44 \%)\end{array}$ & $\begin{array}{l}34 \text { females } \\
(47.89 \%)\end{array}$ & & \\
\hline \multicolumn{2}{|c|}{ BMI $\left(\mathrm{kg} / \mathrm{m}^{2}\right)$} & КНМС & $25.2 \pm 0.06$ & $22.21 \pm 0.04$ & $25.26 \pm 0.04$ & $26.51 \pm 0.04$ & $24.79 \pm 0.04$ & 0.89 & NS \\
\hline
\end{tabular}

Data are presented as Mean difference \pm SEM or as percentage by using One-Way ANOVA test (at $p$ value $<0.05)$.

Sig: Significance;

S*: Significant;

NS: Non-significant.

BMI: Body mass index;

KHMC: King Hussein Medical.

Group I: Hemodialysis participants who are taking PPIs $+\mathrm{CaCO}_{3} / \mathrm{MgCO}_{3}$ combination chewable tablets.

Group II: Hemodialysis participants who are taking $\mathrm{H}_{2}$-Blockers $+\mathrm{CaCO}_{3} / \mathrm{MgCO}_{3}$ combination chewable tablets.

Group III: Hemodialysis participants who are taking PPIs + only $\mathrm{CaCO}_{3}$ tablets.

Group IV: Hemodialysis participants who are taking $\mathrm{H}_{2}$-Blockers + only $\mathrm{CaCO}_{3}$ tablet. 
Table 3: Other demographic characteristics of the four studied groups

\begin{tabular}{|c|c|c|c|c|c|c|c|c|}
\hline \multicolumn{2}{|c|}{ Characteristics } & $\begin{array}{c}\text { Group I } \\
\text { N=15 } \\
\text { Mean } \pm \text { SEM }\end{array}$ & $\begin{array}{c}\text { Group II } \\
\text { N=19 } \\
\text { Mean } \pm \text { SEM }\end{array}$ & $\begin{array}{c}\text { Group III } \\
\text { N=19 } \\
\text { Mean } \pm \text { SEM }\end{array}$ & $\begin{array}{c}\text { Group IV } \\
\text { N=18 } \\
\text { Mean } \pm \text { SEM }\end{array}$ & $\begin{array}{c}\text { Total } \\
\text { N=71 } \\
\text { Mean } \pm \text { SEM }\end{array}$ & $\begin{array}{c}P \text { - } \\
\text { Value }\end{array}$ & Sig \\
\hline \multicolumn{2}{|c|}{ Duration of dialysis (months) } & $127.33 \pm 22.79$ & $97.68 \pm 15.34$ & $64.63 \pm 6.64$ & $93.44 \pm 11.63$ & $94.03 \pm 7.49$ & 0.04 & $\left(\mathrm{~S}^{*}\right)$ \\
\hline \multicolumn{2}{|c|}{$\begin{array}{l}\text { Duration of using } \mathrm{CaCO}_{3} \text { tab } \\
\text { as phosphate binder (months) }\end{array}$} & $127.33 \pm 22.79$ & $97.68 \pm 15.34$ & $64.63 \pm 6.64$ & $93.44 \pm 11.63$ & $94.03 \pm 7.49$ & 0.04 & $\left(\mathrm{~S}^{*}\right)$ \\
\hline \multicolumn{2}{|c|}{$\begin{array}{l}\text { Duration of using either PPIs } \\
\text { or } \mathrm{H}_{2} \text {-Blockers (months) }\end{array}$} & $99.33 \pm 24.48$ & $75.47 \pm 11.14$ & $64.63 \pm 6.64$ & $90.33 \pm 11.99$ & $81.38 \pm 6.95$ & 0.32 & $(\mathrm{NS})$ \\
\hline \multicolumn{2}{|c|}{ HD duration per session (hours) } & $4.27 \pm 0.14$ & $4.18 \pm 0.11$ & $3.97 \pm 0.06$ & $4.08 \pm 0.06$ & $4.12 \pm 0.05$ & 0.16 & $(\mathrm{NS})$ \\
\hline \multirow{4}{*}{$\begin{array}{l}\text { HD frequency } \\
\text { per week }(\%)\end{array}$} & $1 *$ per week & $0(0 \%)$ & $1(5.3 \%)$ & $0(0 \%)$ & $0(0 \%)$ & $1(1.4 \%)$ & \multirow[t]{4}{*}{0.31} & \multirow[t]{4}{*}{$(\mathrm{NS})$} \\
\hline & $2 *$ per week & $7(46.7 \%)$ & $5(26.3 \%)$ & $2(10.5 \%)$ & $5(27.8 \%)$ & $19(26.8 \%)$ & & \\
\hline & $3 *$ per week & $7(46.7 \%)$ & $13(68.4 \%)$ & $17(89.5 \%)$ & $13(72.2 \%)$ & $50(70.4 \%)$ & & \\
\hline & $4 *$ per week & $1(6.7 \%)$ & $0(0 \%)$ & $0(0 \%)$ & $0(0 \%)$ & $1(1.4 \%)$ & & \\
\hline
\end{tabular}

Data are presented as Mean difference \pm SEM or as percentage by using One-Way ANOVA test (at $p$-value $<0.05$ ). Sig: Significance.

S*: Significant.

NS: Non-significant.

CaCO3: Calcium carbonate.

PPIs: Proton pump inhibitors.

HD: Hemodialysis.

Group I: Hemodialysis participants who are taking PPIs $+\mathrm{CaCO}_{3} / \mathrm{MgCO}_{3}$ combination chewable tablets.

Group II: Hemodialysis participants who are taking $\mathrm{H}_{2}$-Blockers $+\mathrm{CaCO}_{3} / \mathrm{MgCO}_{3}$ combination chewable tablets.

Group III: Hemodialysis participants who are taking PPIs + only $\mathrm{CaCO}_{3}$ tablets.

Group IV: Hemodialysis participants who are taking $\mathrm{H}_{2}$-Blockers + only $\mathrm{CaCO}_{3}$ tablet. 
Table 4: Tested variables differences within the comparative groups

\begin{tabular}{|c|c|c|c|c|}
\hline $\begin{array}{c}\text { Comparative } \\
\text { Groups } \\
\text { Affective } \\
\text { Variables }\end{array}$ & $\begin{array}{c}\text { Group } 1 \\
\text { after } \\
\text { Versus } \\
\text { Group I } \\
\text { before }\end{array}$ & $\begin{array}{l}\text { Group II } \\
\text { after } \\
\text { Versus } \\
\text { Group II } \\
\text { before }\end{array}$ & $\begin{array}{c}\text { Group III } \\
\text { after } \\
\text { Versus } \\
\text { Group III } \\
\text { before }\end{array}$ & $\begin{array}{c}\text { Group IV } \\
\text { after } \\
\text { Versus } \\
\text { Group IV } \\
\text { before }\end{array}$ \\
\hline $\begin{array}{c}\text { Constipation scoring } \\
\text { System } \\
(0-30)\end{array}$ & $-12(8)$ & $-9(20)$ & $0(4)$ & $0(11)$ \\
\hline (Sig) & $\left(\mathrm{S}^{*}\right)$ & $\left(\mathrm{S}^{*}\right)$ & (NS) & (NS) \\
\hline Serum $\mathrm{cCa}^{+2}$ level & $+0.21 \pm 0.47$ & $+0.08 \pm 0.48$ & $+0.09 \pm 0.19$ & $+0.23 \pm 0.39$ \\
\hline (Sig) & (NS) & (NS) & (NS) & $\left(S^{*}\right)$ \\
\hline Serum $\mathrm{Mg}^{+2}$ level & $+0.30 \pm 0.34$ & $+0.55 \pm 0.36$ & $+0.05 \pm 0.17$ & $+0.12 \pm 0.17$ \\
\hline (Sig) & $\left(S^{*}\right)$ & $\left(S^{*}\right)$ & (NS) & (NS) \\
\hline
\end{tabular}

Data are presented as Mean difference \pm SD or as median difference (Range) and are analyzed by using Paired T-Test or Wilcoxon Signed Ranks Test (at p-value $<0.05$ ).

Sig: Significance.

$\mathrm{S} *$ : Significant

NS: Non-significant.

$\mathrm{cCa}^{+2}$ : Corrected serum Calcium level.

$\mathrm{Mg}^{+2}$ : Serum Magnesium level.

Group I: Hemodialysis participants who are taking PPIs $+\mathrm{CaCO}_{3} / \mathrm{MgCO}_{3}$ combination chewable tablets.

Group II: Hemodialysis participants who are taking $\mathrm{H}_{2}$-Blockers $+\mathrm{CaCO}_{3} / \mathrm{MgCO}_{3}$ combination chewable tablets.

Group III: Hemodialysis participants who are taking PPIs + only $\mathrm{CaCO}_{3}$ tablets.

Group IV: Hemodialysis participants who are taking $\mathrm{H}_{2}$-Blockers + only $\mathrm{CaCO}_{3}$ tablet. 
Table 5: Tested variables differences between the comparative groups

\begin{tabular}{|c|c|c|c|c|c|c|}
\hline \begin{tabular}{l}
\multicolumn{1}{c}{$\begin{array}{c}\text { Comparative } \\
\text { Groups }\end{array}$} \\
Affective \\
Variables
\end{tabular} & $\begin{array}{c}\text { Group 1 } \\
\text { Versus } \\
\text { Group II }\end{array}$ & $\begin{array}{c}\text { Group I } \\
\text { Versus } \\
\text { Group III }\end{array}$ & $\begin{array}{c}\text { Group I } \\
\text { Versus } \\
\text { Group IV }\end{array}$ & $\begin{array}{c}\text { Group II } \\
\text { Versus } \\
\text { Group III }\end{array}$ & $\begin{array}{c}\text { Group II } \\
\text { Versus } \\
\text { Group IV }\end{array}$ & $\begin{array}{c}\text { Group III } \\
\text { Versus } \\
\text { Group IV }\end{array}$ \\
\hline $\begin{array}{c}\text { Constipation } \\
\text { scoring System (0- } \\
30) \\
\text { (Sig) }\end{array}$ & $\begin{array}{l}-4(14) \\
(\mathrm{NS})\end{array}$ & $\begin{array}{c}-12(10) \\
\left(S^{*}\right)\end{array}$ & $-12(17)$ & $-9(21)$ & $-8(17)$ & $+1(10)$ \\
\hline $\begin{array}{c}\text { Serum } \mathrm{cCa}^{+2} \text { level } \\
(\mathrm{Sig})\end{array}$ & \multicolumn{6}{|c|}{$\begin{array}{l}\text { Comparison between comparative four groups is insignificant with } \\
\text { p-value equals } 0.569\end{array}$} \\
\hline Serum $\mathrm{Mg}^{+2}$ level & $\begin{array}{c}-0.25 \\
\pm \\
0.09 \\
\\
\left(\mathrm{~S}^{*}\right)\end{array}$ & $\begin{array}{c}+0.25 \\
\pm \\
0.09 \\
\\
\left(\mathrm{~S}^{*}\right)\end{array}$ & $\begin{array}{c}+0.18 \\
\pm \\
0.09 \\
\\
\text { (NS) }\end{array}$ & $\begin{array}{c}+0.51 \\
\pm \\
0.09 \\
\\
\left(\mathrm{~S}^{*}\right)\end{array}$ & $\begin{array}{c}+0.43 \\
\pm \\
0.09 \\
\\
\left(\mathrm{~S}^{*}\right)\end{array}$ & $\begin{array}{c}-0.08 \\
\pm \\
0.09 \\
\\
\text { (NS) }\end{array}$ \\
\hline
\end{tabular}

Data are presented as Mean difference \pm SEM or as median difference (Range) and are analyzed by using Tukey Kramer post-hoc multiple comparison analysis (at p-value $<0.05$ ) and post-hoc multiple comparison analysis using Mann-Whitney U-test and bonferroni correction (at p-value $<0.05)$.

Sig: Significance.

$S *$ : Significant.

NS: Non-significant.

$\mathrm{CCa}^{+2}$ : Corrected serum Calcium level.

$\mathrm{Mg}^{+2}$ : Serum Magnesium level.

Group I: Hemodialysis participants who are taking PPIs $+\mathrm{CaCO}_{3} / \mathrm{MgCO}_{3}$ combination chewable tablets.

Group II: Hemodialysis participants who are taking $\mathrm{H}_{2}-\mathrm{Blockers}+\mathrm{CaCO}_{3} / \mathrm{MgCO}_{3}$ combination chewable tablets.

Group III: Hemodialysis participants who are taking PPIs + only $\mathrm{CaCO}_{3}$ tablets.

Group IV: Hemodialysis participants who are taking $\mathrm{H}_{2}$-Blockers + only $\mathrm{CaCO}_{3}$ tablet.

When comparing between comparative four studied groups, the lowest significant Constipation Scoring System (0-30) value was between Group I and either Group III (-12 (10)) or Group IV (-12 (17)) and highest significant serum magnesium level was between Group II and Group III $(+0.51 \pm 0.09)$ followed by between Group II and Group IV $(+0.43 \pm 0.09)$ which means a positive impacts of
$\mathrm{CaCO}_{3} / \mathrm{MgCO}_{3}$ combination chewable tablets in comparison to $\mathrm{CaCO}_{3}$ tablets regarding constipation in $\mathrm{HD}$ patients who are taking either $\mathrm{H}_{2}$-Blockers or PPIs at the cost of statistically but not clinically significant rising in serum magnesium level, especially when $\mathrm{CaCO}_{3} / \mathrm{MgCO}_{3}$ combination chewable tablets are co-administered with PPIs. 


\section{DISCUSSION:}

The present study found that when $\mathrm{CaCO}_{3}$ tablets were totally replaced by $\mathrm{CaCO}_{3} / \mathrm{MgCO}_{3}$ combination chewable tablets (maximum 6 tablets per day), the Constipation Scoring System (0-30) values were significantly decreased (PPIs $>\mathrm{H}_{2}$-Blockers) due to $\mathrm{Mg}^{+2}$ opposite laxative effect on gastrointestinal motility in contrast to $\mathrm{Ca}+{ }^{2}$ constipating effect with insignificant differences in case of serum corrected calcium. This positive finding of $\mathrm{CaCO}_{3} / \mathrm{MgCO}_{3}$ combination chewable tablets should be balanced with the statistically but not clinically significant rising in serum magnesium levels. These results can be explained based on the correlation between $\mathrm{pH}$ and dissolution/binding kinetic of $\mathrm{CaCO}_{3}$ tablet which can be summarized by "The acidity is best for solubility, but binding to phosphorus is best at higher $\mathrm{pH}$ because at a low $\mathrm{pH}$ the higher $\mathrm{H}^{+}$concentration effectively competes with ionized calcium for binding to phosphorus"18. So, when the $\mathrm{CaCO}_{3}$ tablets are taken with either PPIs or $\mathrm{H}_{2}$-Blockers, the $\mathrm{pH}$ of stomach will be elevated and the acidity that is necessary to dissolve the $\mathrm{CaCO}_{3}$ tablet will be decreased and then the phosphate binding capacity of

\section{REFERENCES}

1. Covic A, Kothawala P, Bernal M, Robbins S, Chalian A, Goldsmith D. Systematic review of the evidence underlying the association between mineral metabolism disturbances and risk of all-cause mortality, cardiovascular mortality and cardiovascular events in chronic kidney disease. Nephrol Dial Transplant. 2009; 24:1506-23.

2. Isakova T, Gutiérrez OM, Chang Y, Shah A, Tamez H, Smith K, et al. Phosphorus binders and survival on hemodialysis. J Am SocNephrol. 2009; 20:388-96.

3. Palmer SC, Hayen A, Macaskill P, Pellegrini F, Craig JC, Elder GJ, et al. Serum levels of phosphorus, parathyroid hormone, and calcium and
$\mathrm{CaCO}_{3}$ tablet will be decreased in contrast of $\mathrm{CaCO}_{3} / \mathrm{MgCO}_{3}$ combination chewable tablet, there is lower problem in dissolution (ratelimiting step) after either chewing or sucking. Furthermore, intestinal absorption of magnesium can also be influenced by calcium and vice versa. High intestinal calcium concentrations have been reported to reduce the absorption of magnesium and subsequently reduce the risk of hypermagnesemia (PPIs $>\mathrm{H}_{2}-$ Blockers).

\section{CONCLUSION:}

In this study, we revealed that $\mathrm{CaCO}_{3} / \mathrm{MgCO}_{3}$ combination chewable tablets may safely be used as first line phosphate binder/calcium supplement instead of the traditional first line phosphate binder/calcium supplement $\mathrm{CaCO}_{3}$ in HD who are taking either PPIs or $\mathrm{H}_{2}$-Blockers with positive impact on severity and frequency of constipation and statistically but not clinically significant risk of persistent hypermagnesemia, especially when we used PPIs instead of $\mathrm{H}_{2}$-Blockers. The shortcoming of our study is that there was no washout period in this study and the sample size was small and should be increased.

risks of death and cardiovascular disease in individuals with chronic kidney disease: a systematic review and meta-analysis. JAMA. 2011;3 05:1119-27.

4. Levin A, Bakris GL, Molitch M, Smulders M, Tian J, Williams LA, et al. Prevalence of abnormal serum vitamin D, PTH, calcium, and phosphorus in patients with chronic kidney disease: results of the study to evaluate early kidney disease. Kidney Int. 2007; 71:31-8.

5. Chiu YW, Teitelbaum I, Misra M, de Leon EM, Adzize T, Mehrotra R. Pill burden, adherence, hyperphosphatemia, and quality of life in maintenance dialysis patients. Clin J Am Soc Nephrol. 2009; 4:108996. 
6. Fissell RB, Karaboyas A, Bieber BA, Sen A, Li Y, Lopes AA, et al. Phosphate binder pill burden, patientreported nonadherence, and mineral bone disorder markers: findings from the DOPPS. Hemodial Int. 2016; 20:38-49.

7. Crivelli O, Pera A, Lombardo L, Vernero S, Varetto $\mathrm{H}$ and Fruttero B. AntralG and D cell counts in chronic renal failure. Scandinavian Journal of Gastroenterology. 1979; 14, 327-331.

8. Carlei F, Caruso U, Lezoche E, Ruscitto G, Laukie P and Casciani U. Hyperplasia of antral $G$ cells in uraemic patients. Digestion. 1984; 29, 26-30.

9. Gold $\mathrm{CH}$, Morley JE, ViljoenM,Tim LO, de Fomseca $\mathrm{M}$ and Kalk WJ. Gastric acid secretion and serum gastrin levels in patients with chronic renal failure on regular hemodialysis. Nephron. 1980; 25, 92-95.

10. Clarkson EM, McDonald SJ and De Wardener HE. The effect of a high intake of calcium carbonate in normal subjects and patients with chronic renal failure. Clinical Science. 1966; 130, 425-438.

11. Tan CC, Harden PN, Rodger RS, Rowe PA, Spooner RJ, Junor JD and Briggs JD. Ranitidine reduces phosphate binding in dialysis patients receiving calcium carbonate. Renal Unit and Department of Biochemistry. 1996; 11(5), 851-853.

12. Hardy P, Sechet A and Hottelart C. Inhibition of gastric secretion by omeprazole and efficiency of calcium carbonate on the control of hyperphosphatemia in patients on chronic hemodialysis. The International Journal of Artificial Organs. 1998; 22, 569-573.

13. Hardy P, Hottelart C, Oprisiu R, AbighanemO, Oualim $\mathrm{Z}$ and Rasombolona M. Role of calcium carbonate administration timing in relation to food intake on its efficiency in controlling hyperphosphatemia in patients on maintenance hemodialysis. The International Journal of Artificial Organs. 2002; 22, 564-568.

14. Takahashi N, Shoji T, Hirohata M, Ishizu T, Miki S, Ono S and Kaifu Y. The effects of histamine $\mathrm{H}_{2}$-receptor antagonists on the phosphorus binding ability of calcium carbonate in hemodialysis patients, Journal of Japanese Society for Dialysis Therapy. 1999; 28, 1069-1074.

15. Hendrix Z, Alcock N and Archibald R. Competition between Calcium, Strontium, and Magnesium for Absorption in the Isolated Rat Intestine. Clinical Chemistry Journal. $1963 ;$ 12, 734-744.

16. Hardwick LL, Jones MR, Brautbar N and Lee DB. Magnesium absorption: mechanisms and the influence of vitamin $\mathrm{D}$, calcium and phosphate. Journal of Nutrition. 1991; 121, 13-23.

17. Schaefer K, Umlauf E and von Herrath D. Reduced risk of hypercalcemia for hemodialysis patients by administering calcitriol at night. American Journal of Kidney Diseases. 1992; 19, 460-464.

18. Carr C and Shangraw R. Nutritional and pharmaceutical aspects of calcium supplementation. Journal of American Pharmacists Association. 2005; 27, 4950, 54- 57. 